\title{
The Political Economy Dynamics of Rural Household Income Diversification: A Review of the International Literature
}

\author{
Gamel Abdul-Nasser Salifu ${ }^{1}$ \\ ${ }^{1}$ Department of Economics, School of Liberal Arts and Social Sciences, Ghana Institute of Management and Public \\ Administration, Achimota, Accra, Ghana \\ Correspondence: Alhaji Gamel Abdul-Nasser Salifu, Lecturer, Department of Economics, School of Liberal Arts and \\ Social Sciences, Ghana Institute of Management and Public Administration, Achimota, Accra, Ghana. E-mail: \\ sgamel@gimpa.edu.gh
}

Received: September 13, 2019

Accepted: October 28, 2019

Online Published: November 30, 2019

doi:10.5430/rwe.v10n3p273

URL: https://doi.org/10.5430/rwe.v10n3p273

\begin{abstract}
This paper presents a summary of the international literature published on the thematic area of the political economy analysis of income diversification related to the activities of rural households with emphasis on the importance of these activities in economic growth, poverty reduction and sustainable development over time. The review provides information about the overall effect of income diversification on economic welfare of rural householders. Typically, a positive relationship exists between income diversification activities and economic welfare indicators such as income, wealth, consumption and nutrition. However, recent empirical literature evidence shows that income diversification could also increase income inequality and contribute to marginalization of certain groups of people. For example, there is evidence to indicate that in some parts of the world that relatively few better-off rural householders with sufficient capital inputs achieve higher levels of income diversification from multiple sources of income portfolios partly due to increased support services from State and community sources. The benefits of income diversification have not been fully realized by many poor rural households largely due to capital constraints, weak links to the political power structures, and conflicts that adversely affect these households. Overall, income diversification can be an important poverty-reducing strategy if its use as a policy strategy is continuously examined and assessed in terms of its political economy dimensions with regards to productivity, equity and sustainability of rural livelihood activities with particular attention paid to vulnerable and marginalized groups.
\end{abstract}

Keywords: diversification, income diversification, non-farm income, off-farm income, economic welfare, poverty, rural households

\section{Introduction}

The growing importance of the services sector in economies around the world fueled by the information and communication technologies, developed over the past 50 years, has influenced the development of rural income diversification into a complex system beyond the narrow scope of off-farm work, which was predominantly linked to the selling of the labour time by farmers to gain additional income. Sustainable income diversification involves the efficient utilization of capital inputs by householders to generate desirable levels of income and well-being from a composite number of income sources (Dedehouann \& McPeak, 2019; Lax \& Kothke, 2017; Dzanku \& Sarpong, 2011, Ellis, 2000a). However, the utilization of capital inputs is contingent on the availability of capital inputs. Rural households' access to capital inputs for income maximization is a critical variant for poverty reduction and economic well-being (Herbinck \& Shackleton, 2018, Bebbington, 1999; Dedehouann et al, 2018). Less endowed rural households often lack capital inputs and are unable to undertake adequate income diversification while better-off households with adequate inputs earn higher shares of wage income from diversified income sources (Ayele, 2019; Agyeman, Asuming-Brempong, \& Onumah, 2014, Senaratna, 2014).

Income diversification is pursued by rural householders as it tends to lower their exposure to risk, vunerability and precarity in areas predisposed to environmental degradation (Adelekan \& Omatayo, 2017; Dimova \& Sen, 2010; Ellis, 2000a). Income diversification improves income levels of better off rural households. Less income-diversified households are often associated with higher levels of income inequality (Nakajima, Otsuka \& Yamano, 2018). The evidence from the economic growth literature suggests that different endowments of capital inputs of rural 
households account for their differences in income diversification portfolios and poverty levels (Allanson \& Barnes, 2017; Gecho, 2017).However, the processes that often lead to quick transitions into and out of poverty are not so clearly defined by the literature and remain an area yet to be explored by emerging economic research, particularly for Sub-Saharan Africa, where rural poverty and structural vulnerability are on the ascendency.

Therefore an understanding of the political economy factors driving income diversification for poverty reduction may be relevant in explaining the income disparities of rural poor and processes that lead to their upward mobility (Salifu \& Anaman, 2019, Wanyama et al., 2010). Political economy analysis of rural income diversification as a tool for poverty reduction and promotion of social and economic well-being is associated with the use of a number of social science theories and tools to evaluate and assess various income-generating sources of rural households. Political economy analysis of income diversification may also be vital in reducing the adverse effects of seasonality by taking advantage of "economies of scope" made possible by specialization (Jonny et al., 2019). The political economy discussions foster the development of new products and innovation through the entrepreneurial opportunities created from income diversification processes by rural householders (Dias et al., 2019, Alemu, 2012).

A further examination of the political economy of income diversification as a poverty reduction and sustainability tool may exert a positive influence on policy-making and could be a real option for building rural livelihoods exacerbated by unsuccessful implementation of policy interventions (Yobe, Mudhara, \& Mafongoya, 2019). Unfortunately poverty reduction studies in sub-Saharan Africa have reduced the phenomenon into a mechanistic social phenomenon addressed by adhoc measures and approaches. These measures have failed to identify the root causes of rural poverty. An integrated political economy study paves the way for improved success of policy interventions through a candid analysis of the socio-cultural psyche of the rural poor. The application of political economy analysis in income diversification activities is expected to drive the "rural renaissance' efforts of State and community organizations to improve the rural non-farm economy and well-being of households (Ali, Deninger, \& Duponchel, 2014; Hanson, 2012). This could lead to an overall improvement in welfare outcomes for rural householders (Kirk, Killic, \& Carletto, 2018). The growing importance of political economy analysis of income diversification can be not over-emphasized. It may be seen in its positive linkages to consumption patterns, food and nutritional security of rural householders (Adem et al., 2018, Asmah, 2011).

The main objective of this review is to assemble the various theories and empirical works undertaken in the thematic areas of income diversification that provide cross-cultural and multidisciplinary approaches in understanding the strategy of diversification as a multi-purpose tool used for raising rural household incomes, reducing risk and uncertainty of livelihood activities and advancing the welfare of rural households in various non-economic aspects. The use of political economy approach as the defining basis of this literature review is due to the assembly of various theories and empirical works that cut across social science disciplines in evaluating income diversification opportunities in advancing the welfare of rural households.

The rest of this paper is organized as follows: the next section deals with the classification of income diversification activities undertaken by rural households and the measurement of income diversification. This is followed by the discussion of the benefits of income diversification structured around its use as a poverty reduction tool, as a method for handling household shocks and disturbances which may come from the natural world and/or those from human-induced causes, and as an important means for achieving resilience in terms of dealing with the annual variability in incomes. The drivers of income diversification are then discussed followed by the political economy analytical approaches used for the study of income diversification. The conclusions, acknowledgments and references follow. This paper contributes to the international literature by providing a synthesis of research works in the area of income diversification over the last several decades highlighting some gaps that prompt new research works to advance the use of income diversification as a tool to achieve sustainable economic development.

\section{Definition and Classification of Income Diversification Activities by Rural Households}

Rural income diversification measures revolve around the consensus view that agriculture is the primary source of livelihood activity (Amadou, 2019). Diversification then implies activities undertaken outside agricultural-related enterprises. Income diversification deals both with broad groups of livelihood activities and within a particular group of livelihood activity. Broad groups of livelihood activities include (1) agriculture (crop and livestock production), (2) wage-based employment, (3) self-employment activities outside the agricultural sector, especially in the services sector, such as buying and selling activities, (4) renting of assets and (5) remittances (Perge \& Mckay, 2016; Salifu and Anaman, 2019). Within-group livelihood diversification then implies the undertaking of various activities within a broad group, for example, crop diversification which entails the production of different crops by a household within the broad agriculture or farming livelihood group. 
Rural households are known to use different income diversification activities and strategies, sometimes combining different activities acroos broad groups at one time (Awotide et al., 2012, Barbien \& Mahoney, 2009). Rural household income diversification of activities may be classified into four major groups depending on the ultimate objective of the rural household decision makers. These are as follows: (1) Accumulation, (2) Consolidation, (3) Compensatory, and (4) Security (Dedehouann \& McPeak, 2019; Zoomers, 1999).

\subsection{Accumulation-Led Income Diversification}

Income diversification activities that are considered accumulative are those activities that enhance or upscale the level of capital inputs owned and/or accessed by the rural household with the objective of establishing a minimum threshold of capital inputs required for current income diversification programme while contributing to future expansion plans (Tithy et. al., 2017). Through accumulative strategies of diversification, rural households gain a better leverage for securing higher incomes from diversification activities and upward mobility in terms of non-economic benefits such as increased levels of leisure, community engagement and general wellbeing. Strategies that are used for accumulative-based income diversification include migration, off-farm wage-based work, acquisition of land for further development or for sale in a future period, and development of various forms of housing assets (Imai, Gaiha, \& Thapa, 2015).

\subsection{Consolidatory-Led Income Diversification}

Consolidation, when used for income diversification, implies an increase in the number of income-generating activities with a clear intention of income stabilization over a definite period of time (Saha, 2015). Rural households which utilize consolidatory strategies tend to command higher shares of incomes from diversification activities than rural households that tend to be less consolidatory-minded (Nagle \& Naude, 2013). A high-level of capital inputs may be required for the effective consolidation of diversification of income activities (Olale, Henson \& Cranfield 2010). Actions that are considered to be consolidative include renting some assets and properties of the household such as rooms of the house to government and private sector workers (Oluwatusin \& Sekumade, 2016).

\subsection{Compensatory-Led Income Diversification}

Rural households adopt compensatory income diversification strategies in the event of sudden income gaps due to shocks from crop failure or loss of livelihoods from natural disasters (Jha, 2013). In order to deal with such sudden shocks, rural households may undertake new income diversification activities such as selling of labour and capital inputs including family-owned jewellery and other assets. Borrowing from family members and formal credit-based institutions are also sources used to undertake income diversification activities (Nakajima et al., 2018).

\subsection{Security-Based Income Diversification}

Security-based income diversification activities are those involving the adoption of livelihood activities that ensure enhanced protection against risks arising from environmental and natural hazards (Kahsay \& Mulugeta, 2014), and also human-induced hazards such as conflicts, communal violence and civil wars. In this vein, the movement of a household from an ecologically-unstable area to a more secure environment that reduces the exposure to environmental hazards is considered a major form of security-based income diversification. The relatively large number of farmers who moved from Liberia to Ghana during the Liberian civil war in the 1980s can also be considered a form of security-based income diversification that ensured the survival, personal safety and movable assets of the Liberian refugees. Security income diversification strategies may also include activities that ensure less concentration of agricultural activities in a narrow band of external influences. Thus the use of multi-cropping and multi-tasking, exploring non-agricultural opportunities, sharecropping and stockpiling allow for a wider range of goods to be produced which are not subjected to a particularly-pervasive risk (Zoomers, 1999).

\section{Measures of Rural Income Diversification}

Income diversification strategies used by rural households may cover activities in the entire spectrum of the economy such as agriculture and primary industries, industrial sector and the services sector. In the modern world, which is characterized by extensive ownership of mobile phones, income diversification possibilities have increased substantially requiring the regular updating of measures of diversification of activities by rural households. The methods used to measure income diversification are extensively reported in the literature (see for example, Barrett et al., 2001; Haggblade et al., 2005; Reardon, 1997; Reardon \& Taylor, 1996; Reardon, Taylor, Stamoulis, Lanjouw, \& Balisacan, 2000). In particular, the renewed interest on the political economy analysis of income diversification activities has yielded additional measures of diversification of specific interest for the rural economy (FAO, 1998; Losch et al., 2012; Reardon, 1997; Reardon \& Taylor, 1996; Reardon et al., 2000; Salifu and Anaman, 2019). 
The often-cited measures of income diversification include the Herfindahl-Hirschmann Concentration Index, Simpson Index, Count Index, Margalef Index, Berger-Parker Index, Bhatia Index, Index of Maximum Proportion, Shannon Index, Ogive Index, Entropy, Modified Entropy, and Composite Entropy Indices (Marchetta, 2013; Chaplin, Davidova \& Gorton, 2004; Salifu \& Anaman, 2019). Probably, the most familiar diversification index is the Herfindahl-Hirschman Concentration index (HHCI) (Hirschman, 1945; Herfindahl, 1950; Herfindahl, 1959; Hirschman, 1964: Hall \& Tideman, 1967). HHCI is technically a concentration index which establishes the overall concentration of income-generating activities for a household or a decision maker. It is calculated by the sum of squares of the income shares attributed to each income-generating activity undertaken by the household as a proportion of the total household income.

The origin of HHCI is a subject of historical debate in the literature as to its original proponents. Hirschmann (1945) is now widely accepted as the original source of the HHCI even though its popularization started with its use in the Doctor of Philosophy degree produced by Herfindahl in 1950. Derived from the HHCI, one of the most widely-used diversification indices is based on the work of Simpson (1949). The Simpson Index (SI) is simply 1-HHCI, underlying its use as a measure of spread of all income-generating activities rather than concentration implied in the HHCI. The SI is defined as follows in Equation 1.

$$
\mathrm{SI}=1-\Sigma \mathrm{Pi}^{2}
$$

Equation 1

where SI is the Simpson overall diversification index for a household.

$\mathrm{Pi}$ is the share of total gross income of a household generated from income source $\mathrm{i}$.

The HHCI for a household is denoted by $\Sigma \mathrm{Pi}^{2}$.

\section{General Benefits of Rural Income Diversification}

As argued by Ellis (2003), income diversification is a process through which people develop an increasingly-diverse portfolio of activities and assets to improve their living standards. The benefits of income diversification across industries have been examined by various works (for example, see the works of Ansoms \& McKay, 2010; Bird \& Shepherd, 2003; Ellis and Bahiigwa, 2003; Ellis and Mdoe, 2003; Ellis et al., 2003; Soltani et al., 2012, Yobe et al., 2019; Zafra-Calvo \& Moreno-Peñaranda, 2018). In particular, the role of income diversification as a form of risk reduction and income stabilization that ensures consistent consumption patterns is noted (Barrett, Reardon \& Webb, 2001; Biggs, Gupta, Saikia \& John, 2018). Income diversification also engenders improvements in quality of life, wealth accumulation, food security for rural households (Chavas \& Difalco, 2012; Perge \& Mckay, 2016).

The economic growth studies literature have emphasized the critical role of income diversification in poverty reduction (refer to the works of Abdulai \& CroleRees, 2001; Bezu et al., 2012; Block \&Webb, 2001; Carswell, 2002; Ellis, 1998, 2000a; Gautam \& Anderson, 2016, Niehof, 2004; Smith et al., 2001). The merits of income diversification are also seen in its ability to reduce overall inequality among rural populations (Katchova, 2005; Winters et al., 2010). In terms of poverty reduction, income diversification may occur as a voluntary or an involuntary response to crisis, which can either diminish or accentuate rural inequality depending on the level of access to capital inputs crucial for income diversification (Ellis, 2000a, Seratna, 2014).

Income diversification results in a shift of the rural economy from farm activities to non-farm activities leading to the expansion of the economy reducing both underemployment and unemployment (Aryeetey \& Baah-Boateng, 2015). In contrast, rural households that are limited in income diversification have remained vulnerable and their food security worsened by seasonal changes in food prices and in the agricultural production cycle (Canagarajah et al., 2001; Winters et al., 2010; Zerai \& Gebreegziabher, 2011). Given context-specific factors such as poverty, policy pressures and the overarching socio-political setting limiting income diversification (Hansson, Ferguson, \& Olofsson, 2010, Scoones, 2009), the process of income diversification can be a struggle for survival or as an opportunity for income generation from several income sources (Ellis, 1998; Sen, 1999, Walelign, 2016).

\section{Rural Household Income Diversification and Poverty Reduction}

While many studies have increasingly discussed the role of income diversification in reducing poverty through diversified sources of incomes, a distinction between poverty and low income in the economic growth literature is not always clear (Krishna, 2004). Income-generating activities are livelihood activities that indicate means through which people earn their "daily bread". Poverty, on the other hand, is an outcome-based measure of performance which may be linked to the degree of income diversification (Muyanga, Jayne, \& Burke, 2013, Shorrocks, 1978). The conventional definition used by the World Bank defines the "poor" as those with consumption expenditures below US\$1.90 per person per day based on 2015 constant values (World Bank, 2019). The Human Development 
Index (HDI), developed by the United Nations Development Programme (UNDP), has expanded the definition of poverty to include political economy parameters. This new definition incorporates human and political capital variables as ingredients in the derivation of outcome-based indicators for poverty analysis.

Apart from the HDI, The Organization for Economic Co-operation and Development (OECD) (2001) and World Health Organization (WHO) (1997) have developed other indicators for poverty assessment frameworks in Sub-Saharan Africa which include access to Information Communication and Entertainment (ICE) capital inputs, using indicators ranging from income, access to leisure, income resilience and vulnerability of rural households to income shocks and fluctuations (Adato, Carter, \& May, 2006). The United Nations Environment Programme (UNEP) has taken this concept even further to incorporate indicators of subjective and relational 'wellbeing' (UNEP, 2004). UNEP adds political economy variables related ethnicity, cultural and religious practices and the ability to enhance income diversification from several income sources as important variables in its indicators of human wellbeing. It has been suggested that political-economy capital should be added to the sustainable livelihood framework (Bird, \& Shinyekwa, 2004), stressing the relevance of governance and structuralism factors in human wellbeing.

Although rural poverty is widespread in many regions, the causes of this pervasive condition have been largely discussed in the academic literature with a bias towards the results derived from economic science and econometric modeling (Doss, 2006; Macfadyen \& Corcoran 2002; FAO, 1998). This general assumption of economic dimensions as key variables of poverty and income diversification fails to account for the wide range of differences in the potential incomes status of people of different religions and ethnic groups (Gladwin et al., 2001). For instance rural populations in the three Muslim-dominated Northern regions of Ghana earn lower wages and experience higher incidences of structural poverty and vulnerability than their non-Muslim counterparts in the southern parts of Ghana. A factor that may explain for these differences is the political power dimension. The key political power-wielding individuals in Ghana have tended to come from the southern parts of the country and these people tend to be influenced by the needs and pressures from the relatively large populations from the southern parts of the country.

Incidentally, a great deal of goodwill has come from the international community of the Western world to support the Muslim-dominated rural population of Northern Ghana. Progress on understanding the relationships between income diversification and poverty has been hampered by the limited understanding of factors influencing income diversification and economic well-being in Northern Ghana. One notable government intervention in Northern Ghana since independence in 1957, was the establishment of the Savanna Accelerated Development Authority (SADA) to foster income diversification activities among rural populations with the view to stimulating economic growth and achieving poverty reduction. However, the intervention failed to achieve project objectives for lack of application of political economy approaches to the core underlying problem in the north.

The collapse of SADA was largely due to its principal focus on the acquisition of capital assets rather than on people as the core objective of the Authority. Similarly, economic studies of income diversification among rural households that account for the scope of poverty - other than income and assets - are lacking in the developing world especially in Sub-saharan Africa (Jin \& Jayne, 2011; Narayan et al., 2000). Awareness of these gaps in understanding income diversification and poverty is growing in rural nonfarm economy literature. The international community such as the UN Food and Agriculture Organization (FAO) has continued to advocate for a better understanding of the political-economy conditions of rural communities, as part of efforts to ensure poverty reduction and food security in rural communities (Beyene, 2008; Moore, 2004).

\section{Income Diversification as a Response to Risks and Shocks}

The analysis of the impact of risks and shocks on consumption and income diversification is undertaken using three main approaches. These are: (1) examining risks, shocks and consumption smoothing over time; (2) analysis of the income diversification strategies adopted in response to shocks; and (3) exploring the determinants of consumption 'insurance' among rural households (Fentahun, Seid, \& Biruk, 2018). Previous studies looked at the rural sector contextually without detailed correlation analysis between consumption insurance and income diversification (Bird \& Shinyekwa, 2004, Townsend, 1994; Ravallion \& Chaudhuri, 1997, Habiyaremye, 2017). Other empirical studies (Friedman, 1957; Meghir, 2004) have investigated the overall effect of shocks on consumption. The findings of these studies have created the basic hypothesis for the investigation of the relationship between rural income diversification and consumption patterns of rural households.

Overall, the evidence on the response mechanisms of rural households to shocks tend to accept the hypothesis that many households are not adequately resourced to safeguard themselves from income fluctuations, food crisis and other structural precarities (Adelekan \& Omotayo, 2017; Folke, Colding, Berkes, 2003). Although other studies on the contrary have rejected this hypothesis with the conclusion that rural households, depending on their context, are 
adequately resourced to insure themselves partially against the most devastating shocks and crisis (Heltberg \& Lund 2009; Wan et al., 2016). Attanasio and Sze kely (2004) suggest that Mexican rural households are unable to insure consumption against household head's wage income fluctuations. Czudec and Zajac (2017) provide evidence from Poland that risk pooling is not achieved in a rural area despite quite extensive borrowing and lending between rural households. Maccini and Yang (2009) show that changes in weather conditions, such as high rainfall patterns, constitute an aggregate shock for rural households with long-term implications for their income diversification abilities. Dercon (2004) indicates that in Ethiopia climate change events and shocks exert a negative influence on income diversification opportunities of rural households. Emerging literature has called for the design and adoption of income diversification insurance among rural households (Gine et al., 2008; Upton, Cissé, \& Barrett, 2016).

A major literature gap exists, in establishing the relationship between income diversification and different types of risks that rural households are exposed to (Walelign, 2016). Empirical evidence has shown a positive correlation between income diversification and climate change events (Dinar, Hassan, Mendelsohn, \& Benhin, 2012). However, these resesearch works have not fully identified the effect of different shocks on income generation activities of rural households and their income streams over different periods of time. It is also interesting to examine the risk management strategies adopted by rural households in the face of major income diversification shocks. This area with regard to the political-economy analysis of rural households has not been well documented.

\section{Income Diversification and Household Resilience}

Political economy analysis of income diversification as a concept basically seeks to understand how households currently generate income from different income sources, attempting to meet their various consumption and economic necessities and at the same time coping with uncertainties, and responding to new income diversification opportunities in the near future (Gautam, \& Andersen, 2016; de Haan \& Zoomers, 2005). The political economy approach to the study of income diversification and the level of resilience of rural households in responding to uncertainties is essential and context specific (Habiyaremye, 2017; Kirkby et al., 2001). The conventional development literature has approached the analysis of income diversification and resilience from the vulnerability and social security perspective leaving little room for the political economy aspects of household resilience to income shocks (Blaikie 1995, Kiryluk-Dryjska, \& Beba, 2018).

Several other studies have examined the adaptation patterns of rural households to income resilience both in the short-term period (Davies et.al, 2009, Murawska, 2018) and in the long-term period (Singh \& Gilman 1999; Czudec \& Zajac, 2017). A representative statement by Chambers and Conway (1992:6) indicated that "an income generating activity is sustainable for rural households when it can cope with and recover from stresses and shocks, maintain or enhance its capabilities, assets and entitlements, while not undermining the natural resource base." However, few income diversification studies have pursued the agenda of how rural households "can cope with and recover from stresses and shocks," and the resilience analysis that this would entail (Akinrinde, Omotesho, \& Ogunla, 2018).

Understanding the political economy of income diversification becomes crucial in managing the effects of stresses and shocks on rural households prone to crisis. This is because stresses and shocks that impinge upon income diversification activities of rural households are a product of the political economy of interactions between global forces and local contexts (Armitage \& Johnson 2006; de Haan 2000). Fluctuations in availability of capital resources and inputs, seasonality of capital input utilization, and changes in political economy variables shaping access, create challenges for rural households in income diversification endeavours (Hassan, Hossain, Sultana, \& Ghosh, 2015; Joshi, Gulati, Birthal, \& Twari, 2003). Although the economic drivers of income diversification recognizes the role of world markets and unaffordable credit in income diversification, political economy and policy drivers, such as misguided government programmes, create the most devastating stresses and shocks for the quality of life of rural populations (Hansson, Ferguson \& Olofsson, 2010; Porter, 2012; Pritchard, Grundy, Horst, \& Ryan, 2019).

\section{The Drivers of Rural Household Income Diversification}

Political economy analysis of income diversification assumes that rural households are driven by multifaceted and multi-dimensional factors to diversify their income sources. These factors may be classified into three major groups of factors influencing income diversification among rural householders; the economic factors of push and pull, the political factors of institutions, and social factors (Ellis, 2000b; Reardon, Berdegué, Barrett, \& Stamoulis, 2006 Konigs, 1986).

\subsection{Push Factors}

Push factors are the undesirable stressful factors which compel rural householders to seek alternative income sources in addition to primary farm income. The push drivers of income diversification reflect the demand-side related 
socio-economic factors which motivate the income generating activities and scope of rural households. Push income diversification is predominant among risk-averse rural households employed in low return non-farm income generating activities. One major attribute of push diversification is that it is highly unsustainable, both environmentally and economically, with low potential as a poverty reduction tool for securing better welfare impacts on rural households (Ellis, 1998, 2000b, Haggblade et al., 2007).

The main goal of push income diversification strategy is to mitigate risk and reduce income volatility among rural households exposed to environmentally degradable agriculture (Barrett et al., 2001; Dercon, 2004; Ellis, 2000b; Matlon, 1991). Push income diversification although unsustainable may still be all the more important for rural households because of the apparent absence of social protection and safety nets in the developing world to insure them against risky agriculture. In Ghana, and especially in the five northern regions, push income diversification tends to peak in the dry season when there is a significant decline in farm income (Reardon, 1997; Salifu \& Anaman, 2019). Rural households therefore rely on off-farm activities such as selling of farm products, migration, remittances and paramilitary escapades to supplement household incomes (Ellis, 1998; Losch et al., 2012; Reardon, 1997, Bryceson, 2002; Grawert, 1998).

\subsection{Pull Factors}

Pull factors are desirable welcome factors which incentivize rural householders to seek additional income sources to improve their standards of living. The pull drivers of diversification are both supply-side and demand-size factors influencing rural income diversification. Rural households are motivated by pull factors to expand their range of income activities from rents, wages, non-farm enterprise, and migration and remittance income sources outside farming. Income diversification, engendered by pull factors, is associated with high potential sustainable agricultural environments with lower risk and uncertainty (Haggblade et al., 2007). The main objective of pull income diversification is to accumulate wealth and generate assets for reinvestment into profitable income generating activities (Ellis, 1998, 2000b; Habiyaremye, 2017). Some examples of income diversification activities driven by pull factors include commercial agriculture, new nonfarm labour market opportunities with linkages to urbanization. For instance, the growing population density of emerging new cities in West Africa such as Tamale and Yendi in the Northern region of Ghana with better market access, improved rural infrastructure, and increased demand for non-food goods and services driven by higher per capita income of Ghana, is a major driver of income diversification and rural entrepreneurship.

\subsection{Social Factors}

Rural household diversification of income activities may be seen as part of an active social process through which rural households seek additional income sources to supplement primary agricultural-based incomes. Social networks, associations such as farmer-based organisations, business development services, and personal positions in community, religion and culture, links to political power structures are important drivers of income diversification in rural areas (Ellis, 1998; Salifu and Anaman, 2019). Income diversification is also driven by differences in relative social importance among rural households in different agro-climatic zones (Reardon, 1997). Access to income diversification opportunities with potential for earning high wage incomes may be engendered and constrained by class, income disparity or social inequalities (Oya, 2007; Start \& Johnson, 2004). Awo and Anaman (2015) established that the price satisfaction received by women for shea nut products was related to their membership of farmer-based organizations. Rural female-headed households with poor access to productive capital inputs for income diversification endeavours register higher levels of food and nutritional insecurity than male headed households (Gladwin, Thomson, Peterson, \& Anderson, 2001).

\subsection{Institutional Factors}

Institutionalism theories suggest that income diversification activities of rural households do not occur in vacuum. These activities are managed and supervised by individuals working with Community and State structures (Weingast \& Wittman, 2006, Chapter 1; Awo and Anaman, 2015). The institutional factors driving income diversification are central to the core tenets of political economy analysis of income diversification in the developing world. Institutions facilitate the efficiency of both markets and government services in the diversification chain. With growing decentralization of rural development institutions, the district assemblies (councils) and their elected Municipal/District Chief executives may be at the heart of income diversification activities of rural households in some parts of Sub-saharan Africa, such as Ghana. Governance structures that facilitate the process of individual citizens directly electing their Mayors and local government representatives and holding them accountable for local government development ultimately engenders income diversification activities of rural households through the supply of local public goods and services. 
Hence, income diversification prospers more with excellent institutions that make rural householders more efficient in the production and marketing activities. For example, the institutions of the State such as the Police Service and Tax Administration Services can enhance or discourage income diversification activities of rural households. In most countries of decentralized management administrations, the impact of institutional factors on income diversification activities of rural households is utterly felt. Institutions may either become bridges or barriers to income diversification activities of rural householders in the developing world or Sub-Saharan Africa. It is noted that institutional factors such as regressive tax systems at district and local levels in some parts of Africa often discourage income diversification activities while Progressive tax systems in Asia and Latin America foster the creation of income diversification opportunities and reduction of the barriers to income diversification (Ellis \& Freeman, 2004).

\section{Empirical-Based Approaches for Political Economy Analysis of Income Diversification}

Ito and Kijima, Matsumoto \& Yamano (2006) show that in Japan, poor rural households impacted by push diversification report higher shares of non-farm income in total household income thresholds than relatively better-off households. Cameron and Worswick (2003), find that Indian rural households allocate a significant proportion of their non-farm income to smooth agricultural income losses. Davis et al. (2010) show that Sub-Saharan Africa is inclined to lower income diversification patterns as compared to other continents in the developing world. Harrower and Hoddinott (2005) indicate that in Mali better off rural households are more inclined to pull diversification as a response to income shocks than poor rural households. Block and Webb (2001) find that lack of non-farm income is perceived as a risk factor in income diversification in Ethiopia. Woldehanna and Oskam (2001) find that in northern Ethiopia, rural households diversify into non-farm activities by engaging in high-return income generating activities.

Better-off rural households engage in pull-driven income diversification, whereas poorer household entertain push-driven diversification. Devereux and Sharp (2006) observe that poor rural households in South Africa undertake many different income diversification activities as a means of survival. In general, the empirical studies on income diversification can be classified into three major groups. These are: (1) 'the household economic model' (Singh, Squire, \& Strauss, 1986; Taylor \& Adelman, 2003), (2) 'the sustainable livelihood approach' (Ashley \& Carney, 1999; Chambers \& Conway, 1992; Scoones, 2009); and (3) 'the political-economy analytic approach' (Salifu \& Anaman, 2019; Start, \& Johnson, 2004).

\subsection{The Household Economic Model}

The household model is used in income diversification analysis when the need arises to draw comparisons between returns to labour from farm activities with the returns to labour from non-farm activities (Becker, 1965; Singh et al. 1986; Dinar et al., 2012; Diniz, 2013). Based on the returns made from farm and non-farm activities, rural households make choices on allocation of their production resources and assets (Yaro, 2006). This approach has been utilized in many income diversification studies across Africa (see the works of Barrett et al., 2001; Reardon, 1997; Reardon, Delgado, \& Matlon, 1992; Davis, Winters, Reardon, \& Stamoulis, 2009; Haggblade, Hazell, \& Brown, 1989, Abdulai \& CroleRees, 2001; Barrett et al., 2001, 2001; Bezu \& Barrett, 2012; Bezu, Barrett, \& Holden, 2012; Canagarajah, Newman, \& Bhattamishra, 2001; Lay et al., 2008; Winters et al., 2009; 2010). The major assumption underlying the use of the household approach is that incomes and preferences are equitably shared between and among household members (Taylor \& Adelman, 2003). Testing this assumption in the real world, it may be noted that access to income diversification opportunities varies among different members of the household, thereby impacting their production decisions and choices (Ellis, 1993). This model also assumes that commodity and service markets function perfectly. However, in the developing world, market failure is a common phenomenon and the model may not be adequate in explaining the challenges posed by market failures and imperfections faced by rural householders with regards to optimal income diversification activities (de Janvry \& Sadoulet, 2006; Ellis, 1993).

\subsection{The Sustainable Livelihood Framework}

The sustainable livelihood framework (SLF) approach, on the other hand, accounts for various sources of capital inputs required to achieve sustainable livelihoods by rural households including those linked to the important role of social relationships. These social capital inputs are important in enhancing access to income diversification opportunities both under duress and intense social shocks (Ashley \& Carney, 1999). The SLF approach captures the social angle of income diversification in the endeavours of rural households (see the works of, Ellis, 2000a; Orr \& Mwale, 2001; Ansoms \& McKay, 2010; Bebbington, 1999; Bird \& Shepherd, 2003; Ellis \& Bahiigwa, 2003). Furthermore, the approach recognizes the multi-dimensional character of income diversification and the important roles to be played by social agents and actors outside the household unit and along what can be called the income diversification chain. However, this approach is sometimes criticized for the use of proxy indicators of subjective 
well-being, which may often be difficult to measure in the empirical analysis of rural income diversification.

\subsection{The Integrated Political Economy Approach}

The 'political economy approach' analyses how the integrated power structures of social relations, institutions, organizations, policies affect the ability of rural households to convert capital inputs into welfare outcomes (Schultz, 1980; Ansoms \& McKay, 2010; Vedeld, Jumane, Wapalila, \& Songorwa, 2012). The political economy approach incorporates the roles of racial, ethnic, gender, political and religious affiliations of targeted beneficiaries in their access of capital inputs required to produce welfare outcomes. This approach has its strength in recognizing the multiple and diverse character of livelihoods (Ellis, 1998, 2000a; Ellis \& Biggs, 2001) and has proved useful in examining the diversity of different groups of people (Estudillo \& Otsuka; 2016; Sourisseau et al., 2012). Furthermore this approach considers the influence of structural dimensions on income diversification behaviour of rural households and the diseconomies of scale faced by powerless minorities in accessing opportunities (Escobal, 2011; Salifu \& Anaman, 2019). Unlike the household approach, it clearly identifies the role to be played by the State, community and international actors through the processes of market failures correction efforts in addressing income diversification constraints faced by rural households to advance their socio-economic development.

Most of the empirical studies of income diversification have been carried out using cross-sectional data. The comparison of different regions are common in the works of (Barrett et al., 2001; Canagarajah et al., 2001; Dercon \& Krishnan, 1996; Losch et al., 2012; Winters et al., 2009, 2010). A few studies have used panel data (see for example the works of Abdulai \& CroleRees, 2001; Bezu \& Barrett, 2012; Bezu et al., 2012; Block \& Webb, 2001; Demeke \& Zeller, 2012; Demissie \& legesse; 2013; Demurger, Fournier \& Yang, 2010; Dercon, 2004; Djurfeldt et al., 2011; Kijima, Matsumoto, \& Yamano, 2006; Lay et al., 2009; Porter, 2012). The major constraint in the use of panel data lies in the lack of financial resources to collect and analyse such data. These financial constraints have limited empirical works of income diversification largely to the use of cross-sectional data with limited scope for making generalizations about income diversification in rural areas (Carletto, Jolliffe, \& Banerjee, 2013).

\section{Overall Effect of Income Diversification on Economic Welfare}

Several studies on income diversification of rural households have found a positive relationship between number of income diversification activities and major economic welfare indicators such as income, wealth, consumption and nutrition (Barrett et al., 2001; Ellis, 1998, 2005; FAO, 1998; Reardon, 1997). Evidence from income diversification studies in Ethiopia suggests that higher share of off-farm income leads to higher levels of consumption resulting in poverty reduction among non-poor rural households (Bezu et al., 2012; Block \& Webb, 2001; Owusu, Akweetey, Jordaan \& Ogundeji, 2018). The studies show that poor rural households are limited by high entry barriers associated with income diversification into high return non-farm sector activities (Abdulai \& CroleRees, 2001; Barrett et al., 2001; Davis et al., 2009) and are confined to low-return income diversification activities (Anderson, 2011; Barrett et al., 2001; Bezu et al.,2012; Marenye et al., 2003).

High-return income diversification opportunities are often found in formal sector employment which require the use of skilled manpower to generate higher levels of income, while the low-return opportunities generally have little requirement for skilled labour or capital (Diniz, 2013; Woldehanna, 2000). Some of these low return unskilled activities include porter jobs, traditional cottage activities, and micro-enterprise like petty-trade, handicrafts, sand mining, brick making, burning charcoal or collecting firewood (Angelsen et al, 2014; Muyanga \& Jayne, 2014; Start \& Johnson, 2004).

Income diversification activities of rural households have direct impact on their agricultural productivity, food and nutrition security. In Sub-saharan Africa, Savadogo, Reardon, \& Pietola (1998) found that rural households that lacked financial assets for farm diversification used their non-farm income to reinvest in animal traction and livestock (Demissie \& legesse; 2013; Mubaya \& Maungoya, 2016). Studies in East Africa by Dercon and Krishnan (1996) found that rural households engaged in income diversification activities with high barriers of entry, had higher levels of income and consumption. Ellis and Mdoe (2003) showed that highly-diversified rural households with a higher share of wage income had higher levels of agricultural productivity than lowly diversified households. Evidence from Kenya shows that the share of wage income from diversification from the formal sector such as salaried work, has positive correlation with agricultural productivity and food security of rural households (Lay et al., 2008; Marenya, Oluoch-Kosura, Place, \& Barrett, 2003).

The relationship between income diversification and economic welfare is one of consumption decisions for the sake of well-being (Bebbington, 1999; Singh, et al., 1986; Pritchard, et al., 2019). Rural household consumption emphasizes necessities such as food, clothing, medicine, shelter, and amenities such as electricity, transport and 
household goods such as radios and motor bikes. The overall impact of income diversification on rural economic welfare is mixed (Barrett et al., 2001; FAO, 1998, Haggblade et al., 2005; Reardon, 1997; Reardon \& Taylor, 1996; Reardon, Taylor, Stamoulis, Lanjouw, \& Balisacan, 2000). Some Sub-saharan Africa studies show that income diversification reduces poverty (Adams, 2002; Van Den Berg \& Kumbi, 2006); others indicate that they tend to increase income inequality (Block \& Webb, 2001; Canagarajah et al., 2001; Reardon \& Taylor, 1996).

There are differences in the nature and returns to labour in different income diversification activities undertaken by rural households according to their income strata, is due to the presence of asset entry barriers (Lay et al., 2009; Reardon \& Taylor, 1996; Woldenhanna \& Oskam, 2001). However, it seems that households with less diversified income sources face higher barriers of entry into new diversification opportunities and continue to struggle over time (Barrett et al., 2001). In Ethiopia, panel evidence (Bezu \& Barrett, 2012; Bezu et al., 2012) shows that rural households who were able to circumvent the barriers of entry into new diversification opportunities subsequently earned higher returns within a short period of time and suffered less vulnerability over time.

Studies have evaluated the effect of income diversification on rural and food poverty and the correlation between rural income diversification (share of off-farm income in total household income portfolio or absolute level of nonfarm income), and total household income has been established (Bezu et al., 2012). However there is conflicting empirical evidence on whether income diversification truly leads to poverty reduction for all rural households. Studies have argued that income diversification is biased in favour of rural households with better factor endowments and may tend to increase income inequality among rural households in different income strata (FAO, 1998; Losch et al., 2012; Reardon, 1997; Reardon \& Taylor, 1996; Reardon et al., 2000).

\section{Conclusions}

The paper provides a summary of theoretical and empirical works in the area of income diversification activities of rural people around the world based on an extensive review of 180 works compiled from all continents of the world. Several findings are identified from this review which raise some important issues and gaps for further research work. Firstly, because of increasing decline in agricultural incomes due to the relative decline of the agricultural sector as compared to the other sectors of the economy (industrial and services), diversification of income sources becomes crucial for rural households. Secondly, the article emphasizes the growing relevance of income diversification activities as tools for economic growth, poverty reduction, food security and creation of employment in rural areas. Evidence from several studies underscore the positive impact of income diversification on rural household welfare indicators such as income, wealth, consumption, nutrition, agricultural productivity and food security. Majority of rural households are not able to diversify their income activities. Government-supported income diversification programmes appear to be biased in favour of relatively better-off rural householders with sufficient capital inputs, while poor householders tend to be constrained by barriers in participating in such programmes.

Although income diversification provides a safety net for the rural poor and sometimes offers a means for upward mobility from poverty, poor households are severely limited in their ability to expand incomes from diversification activities. This justifies the promotion of income diversification policies among rural households by the State, community, and international organizations in order to reduce the numerous constraints for the poor. In order to avoid the exclusion of the poor inherent in many government-supported programmes, there is a need for a more carefully balanced approach that allows for more inclusion of the poor into such programmes.

Thirdly, because of data limitations, political economy analysis of the impact of income diversification on rural household welfare is still not fully addressed. Most studies have so far been conducted using cross-sectional data with an over-bearing use of narrow-based econometric models relying largely on neo-classical economic theories which tend to neglect the power relationships and structures within a society. There is a need for more studies on income diversification that takes a dynamic approach by evaluating the scale and needs of income-generating activities of rural households over a period of time. There is also the need to develop more comprehensive political economy models of income diversification of rural households that are multidisciplinary in nature with these models emphasizing strategies to improve the conditions of the poor through appropriate diversification activities. Finally, the impact of civil wars and conflicts on income diversification activities needs to be more thoroughly analysed from both the economic and social sides.

\section{References}

Abdulai, A., \& CroleRees, A. (2001). Determinants of income diversification amongst rural households in Southern Mali. Food Policy, 26(4), 437-452.

Adams, Jr. R. H. J. (2002). Nonfarm income, inequality, and land in rural Egypt. Economic Development and 
Cultural Change, 50(2), 339-363.

Adato, M., Carter, M., \& May, J. (2006). Exploring poverty traps and social exclusion in South Africa using qualitative and quantitative data. Journal of Development Studies, 42(2), 226-247.

Adelekan, A., \& Omotayo, A. O. (2017). Linkage between rural non-farm income and agricultural productivity in Nigeria: A tobit-two-stage least square regression approach. J Dev Areas, 51(3), 317-333.

Adem, M., Tadele, E., Mossie H., \& Ayenalem, M. (2018). Income diversification and food security situation in Ethiopia: A review study. Cogent Food \& Agriculture, 4, 1513354.

Agyeman, B. A. S., Asuming-Brempong, S., \& Onumah, E, E (2014). Determinants of income diversification of farm households in the western region of Ghana. Quarterly Journal of International Agriculture, 53(1), 55-72.

Akinrinde, A. F., Omotesho K. F., \& Ogunla. I. (2018). The issue of income diversification among rural farming households: Empirical Evidence from Kwara State, Nigeria. Journal of Agribusiness and Rural Development, 3(49), 231-238.

Alemu, Z. G. (2012). Livelihood strategies in rural South Africa: Implications for poverty reduction. Paper presented at the 2012 Conference, Foz do Iguacu, Brazil, August 18-24.

Ali, D. A., Deininger, K., \& Duponchel, M. (2014). Credit constraints, agricultural productivity, and rural nonfarm participation: Evidence from Rwanda (Policy Research working paper; No. WPS 6769). Washington, DC: World Bank Group.

Allanson, P., Kasprzyk, K., \& Barnes A. P. (2017). Income Mobility and Income Inequality in Scottish Agriculture. Journal of Agricultural Economics, 68(2), 471-493.

Amadou, Z. (2019). Food and income diversification decisions as climate change adaptation strategies: Evidence from Kalfou and Tabalak local governments, Tahoua State, Niger Republic. Journal of Development and Agricultural Economics, 11(7), 152-161.

Andersson D. A. (2012). Seasonality and farm/non-farm interactions in Western Kenya. The Journal of Modern African Studies, 50(1), 1-23.

Andersson D. A. (2013). African re-agrarianizing? Accumulation or pro-poor agricultural growth?. World Development, 41, 217-231.

Andersson D. A. (2014). Multi-local livelihoods and food security in rural Africa. Journal of International Development. https://doi.org/10.1002/jid.2991

Andersson, A. (2011). Maize remittances, smallholder livelihoods and maize consumption in Malawi. The Journal of Modern African Studies, 49(1), 1-25.

Angelsen, A., Jagger, P., Babigumira, R., Belcher, B., Hogarth, N. J., Bauch, S., \& Wunder, S. (2014). Environmental income and rural livelihoods: A global comparative analysis. World Development, 64, S12-S28.

Ansoms, A., \& McKay, A. (2010). A quantitative analysis of poverty and livelihood profiles: The case of rural Rwanda. Food Policy, 35(6), 584-598.

Armitage, D., \& Johnson, D. (2006). Can resilience be recognized with globalization and increasingly complex resource degradation in Asian coastal regions?. Ecology and Society, 11(1).

Aryeetey, E., \& Baah-Boateng, W. (2015). Understanding Ghana's growth and success story and job creation challenges. WIDER working paper 2015/140. Helsinki; United Nations University World Institute for Development Economics Research.

Ashley, C., \& Carney, D. (1999). Sustainable livelihoods: Lessons from early experience. London: Department for International Development (DFID).

Asmah, E. (2011). Rural Livelihood Diversification and Agricultural Sector Reforms in Ghana. Paper presented at the annual meeting for the Conference on Economic Development in Africa, Oxford, March 20-22.

Attanasio, O. P., \& Sze'kely, M. (2004) Wage shocks and consumption variability in Mexico during the 1990s. Journal of Development Economics, 73(1), 1-25.

Awo, M. A., \& Anaman, K. A. (2015). Political economy analysis of the production and marketing of shea nut products by women in the Northern region of Ghana. Research in World Economy, 6(4), 1-17.

Awotide, B. A., Awoyemi, T. T., Diagne, A., Kinkingnihoun, F. M., \& Ojehomone, V. (2012). Effect of Income Diversification on Poverty Reduction and Income Inequality in Rural Nigeria: Evidence From Rice Farming 
Households. OIDA Int. J. Sustain. Dev., 5(10), 65-78.

Ayele, B. (2019). Revisiting the status of pastoral women's access to and control over livelihood assets; evidences from Fafan zone, Somali region, Ethiopia: Journal of Agricultural Extension and Rural Development, 16(1), 114-127.

Barbieri, C., \& Mahoney, E. (2009). Why is diversification an attractive farm adjustment strategy? Insights from Texas farmers and ranchers. Journal of Rural Studies, 25, 58-66.

Barrett, C. B., \& Reardon, T. (2000). Asset, activity, and income diversification among African agriculturalists: Some practical issues (SSRN Scholarly Paper No. ID 257344). Madison, WI: University of Wisconsin-Madison Land Tenure Center, USAID BASIS CRSP.

Barrett, C. B., Bezuneh, M., \& Aboud, A. (2001). Income diversification, poverty traps and policy shocks in Côte d'Ivoire and Kenya. Food Policy, 26(4), 367-384.

Barrett, C. B., Bezuneh, M., Clay, D. C., \& Reardon, T. (2001). Heterogeneous constraints, incentives and income diversification strategies in rural Africa (Working Paper No. 14761). Ithaca, NY: Cornell University, Department of Applied Economics and Management.

Barrett, C. B., Reardon, T., \& Webb, P. (2001). Nonfarm income diversification and household livelihood strategies in rural Africa: Concepts, dynamics, and policy implications. Food Policy, 26(4), 315-331.

Bebbington, A. (1999). Capitals and Capabilities: A Framework for Analysing Peasant Viability, Rural Livelihoods and Poverty. World Development, 27(12), 2021-44.

Becker, G. S. (1965). A theory of the allocation of time. The Economic Journal, 75(299), 493.

Beyene, A. D. (2008). Determinants of off-farm participation decision of farm households in Ethiopia, Agrekon, 47(1), 140-161.

Bezu, S., \& Barrett, C. (2012). Employment dynamics in the rural nonfarm sector in Ethiopia: Do the poor have time on their side?. The Journal of Development Studies, 48(9), 1223-1240.

Bezu, S., \& Barrett, C. B. (2012). Employment dynamics in the rural nonfarm sector in Ethiopia: Do the poor have time on their side?. Journal of Development Studies, 48(9), 1223-1240.

Bezu, S., Barrett, C. B., \& Holden, S. T. (2012). Does the nonfarm economy offer pathways for upward mobility?. Evidence from a panel data study in Ethiopia. World Development, 40(8), 1634-1646.

Bhatta, B. P., \& Årethun, T. (2013). Barriers to rural households' participation in low-skilled off-farm labor markets: Theory and empirical results from northern Ethiopia. SpringerPlus, 2(1), 97.

Biggs, E. M., Gupta, N., Saikia, S. D., \& John, M. A. D. (2018). The tea landscape of assam: Multi-stakeholder insights into sustainable livelihoods under a changing climate. Environmental Science \& Policy, 82, 9-18.

Bird, K., \& Shepard, A. (2003). Livelihoods and chronic poverty in semi-arid Zimbabwe. World Development, 31(3), 591-610.

Bird, K., \& Shinyekwa, I. (2004). Multiple shocks and downward mobility: Learning from life histories of rural Ugandans. (Working Paper No. 36). Manchester: Chronic Poverty Research Centre, University of Manchester.

Blaikie, P. (1995). Understanding environmental issues. In S. Morse \& M. Stocking (Eds.), People and the environment (pp. 1-30). UCLA Press, London, UK.

Block, S., \& Webb, P. (2001). The dynamics of livelihood diversification in post-famine Ethiopia. Food Policy, 26(4), 333-350.

Bryceson, D. F. (2002). The scramble in Africa: Reorienting rural livelihoods. World Development, 30(5), 725-739.

Cameron, L. A., \& Worswick, C. (2003). The labor market as a smoothing device: labor supply responses to crop loss. Review of Development Economics, 7(2), 327-341.

Canagarajah, S., Newman, C., \& Bhattamishra, R. (2001). Non-farm income, gender, and inequality: Evidence from rural Ghana and Uganda. Food Policy, 26(4), 405-420.

Carletto, C., Jolliffe, D., \& Banerjee, R. (2013). The emperor has no data! Agricultural statistics in Sub-Saharan Africa (Technical Report). The World Bank

Chambers, R., \& Conway, G. (1992). Sustainable rural livelihoods: practical concepts for the 21st century. IDS Discussion Paper 296, Institute of Development Studies, Brighton, Sussex, UK.

Chaplin, H., Davidova, S., \& Gorton, M. (2004). Agricultural adjustment and the diversification of farm households 
and corporate farms in Central Europe. Journal of Rural Studies, 20, 61-77.

Chavas, J. P., \& Di Falco, S. (2012). On the role of risk versus economies of scope in farm diversification with an application to Ethiopian farms. Journal of Agricultural Economics, 63, 25-55.

Czudec, A., \& Zajac, D. (2017). Non-farming Entrepreneurship in the farm activity diversification process. Journal of Agribusiness and Rural Development, 1(43), 69-78.

Davis, B., Winters, P., Reardon, T., \& Stamoulis, K. (2009). Rural nonfarm employment and farming: Household-level linkages. Agricultural Economics, 40(2), 119-123.

de Haan, L. (2000). Globalization, localization and sustainable livelihood. Sociologia Ruralis, 40(3), 339-365.

de Haan, L., \& Zoomers, A. (2005). Exploring the frontier of livelihoods research. Development and Change, 36(1), 27-47.

De Janvry, A., \& Sadoulet, E. (2006). Progress in the modeling of rural households' behavior under market failures. In A. De Janvry \& R. Kanbur (Eds.), Poverty, inequality and development (pp. 155-181). New York, NY: Springer.

Dedehouanou, S. F. A., \& McPeak, J. (2019). Diversify More or Less? Household Income Generation Strategies and Food Security in Rural Nigeria. The Journal of Development Studies. https://doi.org/10.1080/00220388.2019.1585814

Dedehouanou, S. F. A., Araar, A., Ousseini, A., Abdoulaziz, L. H., \& Jabir, M. (2018). Spillovers from off-farm self-employment opportunities in rural Niger. The Journal of Development Studies.

Demeke, A. B., \& Zeller, M. (2012). Weather risk and household participation in off-farm activities in Rural Ethiopia. Quarterly. Journal of International Agriculture, 51(1), 1-20.

Demissie, A., \& Legesse, B. (2013). Determinants of income diversification among rural households: The case of smallholder farmers in Fedis district, Eastern Hararghe zone, Ethiopia. Journal of Development and Agricultural Economics, 5(3), 120-128.

Démurger, S., Fournier, M., \& Yang, W. (2010). Rural households' decisions towards income diversification: Evidence from a township in Northern China. China Economic Review, 21, S32-S44.

Dercon, S. (2002). Income risk, coping strategies and safety nets. World Bank Research Observer, 17(2), 141-166.

Dercon, S. (2004). Growth and shocks: evidence from rural Ethiopia. Journal of Development Economics, 74(2), 309-329.

Dercon, S., \& Krishnan, P. (1996). Income portfolios in rural Ethiopia and Tanzania: choices and constraints. Journal of Development Studies, 32(6), 850-75.

Devereux, S. (2001). Livelihood Insecurity and Social Protection: A Re-emerging Issue in Rural Development. Development Policy Review, 19(4), 507-19.

Dimova, R., \& Sen, K. (2010). Is household income diversification a means for survival or a means of accumulation? Panel data evidence from Tanzania (BWPI Working Paper Number 122). London: Brooks World Poverty Institute.

Dinar, A., Hassan, R., Mendelsohn, R., \& Benhin, J. (2012). Climate Change and Agriculture in Africa: Impact Assessment and Adaptation Strategies. London: Routledge.

Diniz, F. H., Hoogstra-Klein, M. A., Kok, K., \& Arts, B. (2013). Livelihood strategies in settlement projects in the Brazilian Amazon: Determining drivers and factors within the Agrarian Reform Program. Journal of Rural Studies, 32, no. Supplement C, 196-207.

Djurfeldt, G., Aryeetey, E., \& Isinika, A. C. (2011). African smallholders: Food crops, markets and policy. Wallingford, CT: CABI.

Doss, C. (2006). The effects of intrahousehold property ownership on expenditure patterns in Ghana. Journal of African Economies, 15(1), 149-180.

Dzanku, F. M., \& Sarpong, D. (2011). Agricultural diversification, food self sufficiency and food security in Ghana CABI, Wallingford, UK Google scholar.

Ellis, F. (1993). Peasant economics: Farm households in agrarian development. Cambridge: Cambridge University Press.

Ellis, F. (1998). Household strategies and rural livelihood diversification. Journal of Development Studies, 35(1), 
$1-38$.

Ellis, F. (2000a). Rural livelihoods and diversity in developing countries. New York, NY: Oxford University Press.

Ellis, F. (2000b). The determinants of rural livelihood diversification in developing countries. Journal of Agricultural Economics, 51(2), 289-302.

Ellis, F. (2005). Small-farms, livelihood diversification and rural-urban transitions: Strategic issues in Sub-Saharan Africa. Presented at the future of small farms, Withersdane Conference Centre, Wye, Kent, UK.

Ellis, F., \& Bahiigwa, G. (2003). Livelihoods and rural poverty reduction in Uganda. World Development, 31(6), 997-1013.

Ellis, F., \& Biggs, S. (2001). Evolving themes in rural development 1950s-2000s. Development Policy Review, 19(4), 437-448.

Ellis, F., \& Freeman, H. A. (2004). Rural livelihoods and poverty reduction strategies in four African countries. Journal of Development Studies, 40(4), 1-30.

Ellis, F., \& Mdoe, N. (2003). Livelihoods and rural poverty reduction in Tanzania. World Development, 31(8), 1367-1384.

Escobal, J. (2001). The determinants of nonfarm income diversification in Rural Peru. World Development, 29(3), 497-508.

Estudillo, J. P., \& Otsuka, K. (2016). Moving out of poverty: An inquiry into the inclusive growth in Asia. Abington: Routledge.

Fafchamps, M. (1999). Risk sharing and quasi-credit. Journal of International Trade and Economic Development, $8(3), 257-278$.

Fafchamps, M., \& Lund, S. S. (2003). Risk-sharing networks in rural Philippines. Journal of Development Economics, 71(2), 261-287.

Fentahun G. E., Seid, S., \& Biruk, K. (2018). The Role of Income Diversification on Risk Management and Rural Household Food Security in Ethiopia. Journal of Economics and Sustainable Development, 9(9).

Folke, C., Colding, J., \& Berkes, F. (2003). Synthesis: building resilience and adaptive capacity in social-ecological systems. In F. Berkes, J. Colding \& C. Folke (Eds.), Navigating social-ecological systems: building resilience for complexity and change (pp. 352-387). Cambridge University Press, Cambridge, UK.

Food and Agriculture Organization of the United Nations (FAO). (1998). The state of food and agriculture 1998 (No. FAO Agriculture series No. 31). Rome: FAO.

Friedman, M. (1957). A Theory of the Consumption Function. Princeton, NJ: Princeton University Press for National Bureau of Economic Research.

Gamba, P., \& Mghenyi, E. (2004). Rural poverty dynamics, agricultural productivity and access to resources. (Tegemeo Institute of Agricultural Policy and Development Working Paper Series No. 21/2004). Nakuru: Egerton University.

Gautam, Y., \& Andersen, P. (2016). Rural livelihood diversification and household well-being: Insights from Humla. Nepal. Journal of Rural Studies, 44, 239-249.

Gecho, Y. (2017). Rural farm households' income diversification: The case of Wolaita Zone, Southern Ethiopia. Social Sciences, 6(2), 45-56.

Ghimire, R., Huang, W.-C., \& Shrestha, R. B. (2014). Factors affecting nonfarm income diversification among rural farm households in Central Nepal. International Journal of Agricultural Management and Development, 4(2), $123-132$.

Gine', X., Townsend, R., \& Vickery, J. (2008). Patterns of rainfall insurance participation in rural India. World Bank Economic Review, 22(3), 539-566.

Gladwin, C. H., Thomson, A. M., Peterson, J. S., \& Anderson, A. S. (2001). Addressing food security in Africa via multiple livelihood strategies of women farmers. Food Policy, 26(2), 177-207.

Grawert, E. (1998). Making a living in rural Sudan: Production of women, labour migration of men, and policies for peasants'needs. London: Macmillan.

Habiyaremye, A. (2017). Estimating the impact of sericulture adoption on farmer income in Rwanda: an application of propensity score matching, Agrekon, 56(3), 296-311. 
Haggblade, S., Hazell, P. B. R., \& Reardon, T. (2007). Transforming the rural nonfarm economy: Opportunities and threats in the developing world (490 p). Washington, DC: International Food Policy Research Instititue.

Haggblade, S., Hazell, P., \& Brown, J. (1989). Farm-nonfarm linkages in rural sub-Saharan Africa. World Development, 17(8), 1173-1201.

Haggblade, S., Hazell, P., \& Reardon, T. (2005). The rural nonfarm economy: Pathway out of poverty or pathway in? (pp. 151-178). Presented at The Future of Small-Farms, Withersdane Conference Centre, Wye, Kent, UK.

Haggblade, S., Hazell, P., \& Reardon, T. (2010). The rural non-farm economy: Prospects for growth and poverty reduction. World Development, 38(10), 1429-1441.

Hansson, H., Ferguson, R., \& Olofsson, C., (2010). Understanding the diversification and specialization of farm businesses. Agricultural and Food Science, 19, 269-283.

Hasan, S. S., Hossain, M., Sultana, S, \& Ghosh, M. K. (2015). Women's Involvement in Income Generating Activities and Their Opinion About Its Contribution: A Study of Gazipur District, Bangladesh. Science Innovation, 3(6), 72-80.

Hebinck, P., Mtati, N., \& Shackleton, C. (2018). More than just fields: Reframing deagrarianisation in landscapes and livelihoods. Journal of Rural Studies, 61, 323-334.

Heltberg, R., \& Lund, N. (2009). Shocks, coping, and outcomes for Pakistan's poor: health risks predominate. Journal of Development Studies, 45(6), 889-910.

Imai, K. S., Gaiha, R., \& Thapa, G. (2015). Does non-farm sector employment reduce rural poverty and vulnerability? Evidence from Vietnam and India. Journal of Asian Economics, 36(2), 47-61.

Jayne, T. S., Yamano, T., Weber, M. T., Tschirley, D., Benfica, R., Chapoto, A., \& Zulu, B. (2003). Smallholder income and land distribution in Africa: Implications for poverty reduction strategies. Food Policy, 28(3), 253-275.

Jha, A. K. (2013). Retracted: Climate change and internal migration in India: Response of the state, market, and the civil society. Poverty \& Public Policy, 5(2), 133-145.

Jin, S., \& Jayne, T. S. (2011). Impacts of land rental markets on rural poverty in Kenya. Paper presented at the 2011 Agricultural and Applied Economics Association Annual Meeting, Pittsburgh, PA.

Johny, J., Wichmann, B., \& Swallow, B. M., (2017). Characterizing social networks and their effects on income diversification in rural Kerala, India. World Development, 94, 375-392.

Kahsay, S., \& Mulugeta, M. (2014). Determinants of rural household food insecurity in Laelay Maichew Woreda Tigray. Ethiopia. Afr J Agric Food Security, 2(1), 105-11.

Katchova, A. L. (2005). The farm diversification discount. American Journal of Agricultural Economics, 87, 984-994.

Kijima, Y., Matsumoto, T., \& Yamano, T. (2006). Nonfarm employment, agricultural shocks, and poverty dynamics: Evidence from rural Uganda. Agricultural Economics, 35, 459-467.

Kirk, A., Kilic, T., \& Carletto, C. (2018). Composition of Household Income and Child Nutrition Outcomes Evidence from Uganda. World Development, 109, 452-469.

Kochar, A. (1999). Smoothing consumption by smoothing income: hours-of-work responses to idiosyncratic agricultural shocks in rural India. Review of Economics and Statistics, 81(1), 50-61.

Konigs, P. (1986). The State and Rural Class Formation in Ghana: A Comparative Analysis. London: Routledge and Kegan Paul.

Krishna, A. (2004). Escaping poverty and becoming poor: who gains, who loses, and why?. World Development, $32(1), 121-36$.

Lanjouw, P. (2007). Does the rural nonfarm economy contribute to poverty reduction?. In S. Haggblade, P. Hazell \& T. Reardon (Eds.), Transforming the Rural Nonfarm Economy: Opportunities and Threats in the Developing World (pp. 55-83). Baltimore, MD: Johns Hopkins Press.

Lax, J., \& Köthke, M. (2017). Livelihood strategies and forest product utilisation of rural households in Nepal. Small-scale Forestry, 16(2), 1-16.

Lay, J., Mahmood, T. O., \& M'mukaria, G. M. (2008). Few Opportunities, Much desperation: The dichotomy of Non-Agricultural Activities and Inequality in Western Kenya. World Dev., 36(12), 2713-2732. 
Losch, B., Freguin-Gresh, S., \& White, E. T. (2012). Structural transformation and rural change revisited: Challenges for late developing countries in a globalizing world. Agence Française de Developpement and the World Bank: Washington, DC: World Bank.

Maccini, S., \& Yang, D. (2009). Under the weather: health, schooling, and economic consequences of early-life rainfall. American Economic Review, 99(3), 1006-1026.

Marchetta, F. (2013). Migration and non-farm activities as income diversification strategies; the case of Northern Ghana. Canadian Journal of Development Studies Revue canadienne d'e'tudes du de'veloppement, 34(1), 1-21.

Marenya, P. P., Oluoch-Kosura, W., Place, F., \& Barrett, C. B. (2003). Education, non-farm income and farm investment in landscarce Western Kenya (No. Brief no. 14). Madison, WI: USAID BASIS CRSP.

Matlon, P. J. (1991). Risk in agriculture. Farmer risk management strategies: The case of the West African semi-arid tropics. Washington, DC: The World Bank.

Maye, D., Ilbery, B., \& Watts, D. (2009). Farm diversification, tenancy and CAP reform: Results from a survey of tenant farms in England. Journal of Rural Studies, 25, 333-342.

Meghir, C. (2004). A retrospective on Friedman's theory of permanent income. University College London and Institute for Fiscal Studies.

Moore, K. (2004). Chronic, life-course and intergenerational poverty, and South-East Asian youth. Paper presented to the UN Workshop on Youth Poverty in South-East Asia, Yogyakarta, Indonesia.

Morris, W., Henley, A., \& Dowell, D. (2017). Farm diversification, entrepreneurship and technology adoption: Analysis of upland farmers in Wales. Journal of Rural Studies, 44, 239-249.

Mubaya, C. P., \& Mafongoya, P. (2016). Local-level climate change adaptation decision-making and livelihoods in semi-arid areas in Zimbabwe. Environment Development \& Sustainability, 19(6), 1-27.

Muyanga, M., \& Jayne, T. S. (2014). Effects of rising rural population density on smallholder agriculture in Kenya. Food Policy, 48, 98-113.

Muyanga, M., Jayne, T. S., \& Burke, W. (2013). Pathways into and out of Poverty: A Study of Rural Household Wealth Dynamics in Kenya. Journal of Development Studies, 49(10), 1358-1374.

Nagler, P., \& Naudé, W. (2013). Non-farm entrepreneurship in rural Africa: Patterns and determinants of income diversification.

Nakajima, M., Otsuka K., \& Yamano, T (2018). Jobs Off the Farm: Wealth, Human Capital, and Social Group in Rural Eastern India. Journal of Development studies, 54(1), 111-132.

Niehof, A. (2004). The significance of diversification for rural livelihood systems. Food Policy, 29(4), 321-338.

Olale, E., Henson, S., \& Cranfield, J. (2010). Determinants of income diversification among fishing communities in Western Kenya. Selected Paper Prepared for Presentation at the Agricultural and Applied Economics Association 2010 AAEA, CAES and WAEA Joint Annual Meeting, July 25-27, 2010, Denver, Colorado.

Oluwatusin, F. M., \& Sekumade, A. B. (2016). Farm households income sources diversification behaviour in Nigeria. Journal of Natural Sciences Research, 6(4), 102-111.

Orr, A., \& Mwale, B. (2001). Adapting to adjustment: Smallholder livelihood strategies in Southern Malawi. World Development, 29(8), 1325-1343.

Otsuka, K., \& Yamano, T. (2006). Introduction to the special issue on the role of nonfarm income in poverty reduction: Evidence from Asia and East Africa. Agricultural Economics, 35(3), 393-397.

Owusu-Sekyere, E, Owusu, V., Akwetey, W. Y., Jordaan, H., \&Ogundeji, A. A. (2018). Economic welfare implications of policy changes regarding food safety and quality in Ghana. African Journal of Agricultural and Resource Economics, 13(4), 357-371.

Oya, C. (2007). Stories of rural accumulation in Africa: Trajectories and transitions among rural capitalists in Senegal. Journal of Agrarian Change, 7(4), 453-493.

Perge, E., \& Mckay, A. (2016). Forest clearing, livelihood strategies and welfare: Evidence from the Tsimane' in Bolivia. Ecological Economics, 126, 112-124.

Phimister, E., Roberts, D., \& Gilbert, A. (2004). The dynamics of farm incomes: Panel data analysis using the farm accounts survey. Journal of Agricultural Economics, 55, 197-220.

Porter, C. (2012). Shocks, consumption and income diversification in rural Ethiopia. Journal of Development Studies, 
48(9), 1209-1222.

Porter, C. (2012). Shocks, Consumption and Income Diversification in Rural Ethiopia. Journal of Development Studies, 48(9), 1209-1222.

Pritchard, R., Grundy, I. M., Horst, D., \& Ryan, C.M. (2019). Environmental incomes sustained as provisioning ecosystem service availability declines along a woodland resource gradient in Zimbabwe. World Development, 122, 325-338.

Ravallion, M., \& Chaudhuri, S. (1997). Risk and insurance in village India: comment. Econometrica, 65(1), $171-184$.

Reardon, T. (1997). Using evidence of household income diversification to inform study of the rural nonfarm labor market in Africa. World Development, 25(5), 735-747.

Reardon, T., \& Taylor, J. E. (1996). Agroclimatic shock, income inequality, and poverty: Evidence from Burkina Faso. World Development, 24(5), 901-914.

Reardon, T., Berdegué, J., Barrett, C. B., \& Stamoulis, K. (2006). Household income diversification into rural nonfarm activities. In S. Haggblade, P. Hazell, \& T. Reardon (Eds.), Transforming the rural nonfarm economy (pp. 115-140). Baltimore, MD: John Hopkins University Press. Retrieved from http://papers.ssrn.com/abstract $=1846821$

Reardon, T., Delgado, C., \& Matlon, P. (1992). Determinants and effects of income diversification amongst farm households in Burkina Faso. Journal of Development Studies, 28(2), 264-296.

Reardon, T., Taylor, J. E., Stamoulis, K., Lanjouw, P., \& Balisacan, A. (2000). Effects of non-farm employment on rural income inequality in developing countries: An investment perspective. Journal of Agricultural Economics, 51(2), 266-288.

Saha, B., \& Bahal, R. (2015). Factors leading to success in diversified occupation: A Livelihood analysis in India. Journal of Agricultural Education and Extension, 21, 249-266.

Salifu, G.A.N., \& Anaman, K. A. (2019). Political economy analysis of Income diversification of Rural Households in the Northern Region of Ghana. Applied Economics and Finance, 6(5), 10-34.

Savadogo, K., Reardon, T., \& Pietola, K. (1998). Adoption of improved land use technologies to increase food security in Burkina Faso: Relating animal traction, productivity, and nonfarm income. Agricultural Systems, 58(3), 441-464.

Schultz, T. W. (1980). Nobel lecture: The economics of being poor. The Journal of Political Economy, 88, 639-651.

Scoones, I. (1998). Sustainable rural livelihoods: a framework for analysis. Institute of Development Studies (IDS), Brighton, UK. IDS Working Paper 72.

Senadza, B. (2011). Non-farm Income Diversification in Rural Ghana: Determinants and Implications for Income distribution and Welfare. Verlag Dr. Muller, Saarbrucken.

Senaratna Sellamuttu, S., Aida, T., Kasahara, R., Sawada, Y., \& Wijerathna, D. (2014). How access to irrigation influences poverty and livelihoods: A case study from Sri Lanka. Journal of Development Studies, 50, 748-768.

Shorrocks, A. F. (1978). Income inequality and income mobility. Journal of Economic Theory, 19, 376-393.

Singh, I., Squire, L., \& Strauss, J. (1986). A survey of agricultural household models: Recent findings and policy implications. The World Bank Economic Review, 1(1), 149-179.

Singh, N., \& Gilman, J. (1999). Making livelihoods more sustainable. International Social Science Journal, 51, 539-545.

Smith, D. R., Gordon, A., Meadows, K., \& Zwick, K. (2001). Livelihood diversification in Uganda: Patterns and determinants of change across two rural districts. Food Policy, 26(4), 421-435.

Smith, H. E, Jones, D., Vollmer, F., Baumert, S., Ryan, C. M., Woollen, E., ... Patenaude, G. (2019). Urban energy transitions and rural income generation: Sustainable opportunities for rural development through charcoal production. World Development, 113, 237-245.

Sourisseau, J. M., Bosc, P. M., Fréguin-Gresh, S., Bélières, J. F., Bonnal, P., Le Coq, J. F., \& Dury, S. (2012). Représenter la diversité des formes familiales de la production agricole. Approches théoriques et empiriques. France: UMR MOISA, CIHEAM-IAMM, CIRAD, INRA, Montpellier SupAgro, IRD-Montpellier.

Start, D., \& Johnson, C. (2004). Livelihood options? The political economy of access, opportunity and diversification. Overseas Development Institute (ODI), London, UK. ODI Working Paper 233. Retrieved from 
http://www.odi.org

Taylor, J. E., \& Adelman, I. (2003). Agricultural household models: Genesis, evolution, and extensions. Review of Economics of the Household, 1(1/2), 33-58.

Tithy, D, Naznin, S, \& Elias, H. (2017). Analysis of the Impact of Income Diversification Strategies on Food Security Status of Rural Households in Bangladesh: A Case Study of Rajshahi District. American Journal of Theoretical and Applied Business, 2(4), 46-56.

Townsend, R. M. (1994). Risk and insurance in Indian village. Econometrica, 62(3), 539-591.

Turner, B., Kasperson, R., Matson P., McCarthy J., Corell R., Christensen, L., ... Shiller, A. (2003). A framework for vulnerability analysis in sustainability science. Proceedings of the National Academy of Sciences, 100(14), 8074-8079.

Udry, C. (1994). Risk and insurance in a rural credit market: an empirical investigation in Northern Nigeria. Review of Economic Studies, 61(208), 495-526.

Upton, J. B., Cissé, J. D., \& Barrett, C. B. (2016). Food security as resilience: Reconciling definition and measurement. Agricultural Economics, 47(S1), 135-147.

Walelign, S. Z. (2016). Livelihood strategies, environmental dependency and rural poverty: The case of two villages in rural Mozambique. Environment Development \& Sustainability, 18(2), 593-613.

Wan, J., Ruoxi, L., Wenxin, W., Zhongmei, L., \& Bizhen, C. (2016). Income Diversification: A Strategy for Rural Region Risk Management. Sustainability, 8, 1064.

Wanyama, M., Mose, L. O., Odendo, M., Okuro, J. O., Owuor, G., \& Mohammed, L. (2010). Determinants of income diversification strategies amongst rural households in maize based farming systems of Kenya. African Journal of Food Science, 4(12), 754-763.

Weingast, B. R., \& Whittman, D. A. (2006). The Oxford Handbook of Political Economy. Oxford: Oxford University Press

Whitehead, A. (2006). Persistent poverty in North East Ghana, The Journal of Development Studies, 42(2), $278-300$.

Winters, P., Davis, B., Carletto, G., Covarrubias, K., Quiñones, E. J., Zezza, A., \& Stamoulis, K. (2009). Assets, activities and rural income generation: evidence from a multicountry analysis. World Development, 37(9), $1435-1452$.

Winters, P., Essam, T., Zezza, A., Davis, B., \& Carletto, C. (2010). Patterns of rural development: A cross-country comparison using microeconomic data. Journal of Agricultural Economics, 61(3), 628-651.

Woldenhanna, T., \& Oskam, A. (2001). Income Diversification and Entry Barriers: Evidence from the Tigary Region of Northern Ethiopia. Food Policy, 26(4), 351-365.

World Bank. (2019). Principles and Practice in Measuring Global Poverty. Washington, D.C. World Bank, accessed 5 November 2019.

Wuepper, D., Sauer, J., \& Kleemann, L. (2018). Social Capital, Income Diversification and Climate Change Adaptation: Panel Data Evidence from Rural Ethiopia. Journal of Agricultural Economics, 69(2), 458-475.

Yang, L., Liu, M., Min, Q., \& Li, W., (2018) Specialization or diversification? The situation and transition of households' livelihood in agricultural heritage systems. International Journal of Agricultural Sustainability, 16(6), 455-471.

Yaro, J. A. (2006). Is deagrarianisation real? A study of livelihood activities in rural northern Ghana. The Journal of Modern African Studies, 44(1), 125-156.

Yobe, C. L., Mudhara, M., \& Mafongoya, P. (2019). Livelihood strategies and their determinants among smallholder farming households in KwaZulu-Natal province, South Africa. Agrekon, 58(3), 340-353.

Zafra-Calvo, N., \& Moreno-Peñaranda, R. (2018). Exploring local people's views on the livelihood impacts of privately versus community managed conservation strategies in the ruvuma landscape of North Mozambique-South Tanzania. Journal of Environmental Management, 206, 853-862.

Zerai, B., \& Gebreegziabher, Z. (2011b). Effect of non-farm income on household food security in Eastern Tigrai. Ethiopia: An Entitlement Approach, 1, 2011.

Zoomers, A. (1999). Linking Livelihood Strategies to Development. Experiences from the Bolivian Andes. Amsterdam: Royal Tropical Institute/Center for Latin American Research. 